\title{
STRATEGI PENANGGULANGAN PENGANGGURAN MELALUI PERAN USAHA KECIL MENENGAH (UKM) GENTING
}

\author{
Karimaha $^{\mathbf{a}}$ \\ Ridan Muhtadib \\ Kamalic \\ abcSekolah Tinggi Agama Islam Miftahul Ulum, Pamekasan \\ Email: ; ridanmuhtadi@gmail.com; kamaliahmad999@gmail.com
}

\begin{abstract}
Introduction: Roof tile business is an effort made by someone or a group, tile business is needed by the surrounding community. Because in addition to reducing the number of unemployed tile businesses, it can also improve the economy of the community, both from tile business owners or employees / workers, because in the village of gunung timur, the village of gunung the impression is difficult to be reached by the government. The purpose of this study is to determine the role of tile business on unemployment.

Methods: This research is a qualitative or field research, the data sources used are primary data and secondary data using observation, interview and documentation methods. The research site was carried out at tile SMEs located in Gunung Timur Hamlet in Gunung Kesan Village, Sokobanah District, Sampang Regency.The implementation time of this research was carried out in Januari 2021.

Results: Based on the results of research, the roof tile business has an important role in overcoming the number of unemployed and poverty rates and also increases the income of the people in the village of gunung timur, the village of gunung impression. This is evidenced by the increasing income earned so that it can meet the needs of daily life.
\end{abstract}

Keywords: Role of roof tile business, Overcoming, Unemployment. 


\section{PENDAHULUAN}

Di setiap negara sangat diperlukan pertumbuhan ekonomi sebab adanya pertumbuhan ekonomi menunjukkan kesejahteraan yang tercermin pada peningkatan jumlah pendudduk dan diikuti dengan daya beli masyarakat yang semakin meningkat. Dengan melalui pertumbuhan ekonomi sebuah negara dapat mengubah kondisi atau situasi perekonomiannya menjadi lebih baik dalam waktu tertentu. Hal ini dapat dilihat dari perkembangan pertumbuhan nasional. Perekonomian mengalami pertumbuhan apabila jumlah balas jasa terhadap penggunanaan faktor-faktor produksi pada tahun tertentu lebih besar dari tahun sebelumnya. ${ }^{1}$

Setiap manusia memerlukan harta untuk mencukupi segala kebutuhan hidupnya. Oleh karena itu, manusia akan selalu berusaha memperoleh harta kekayaa. Salah satunya dengan bekerja. Islam mewajibkan setiap muslim khususnya yang memiliki tanggungan, untuk "bekerja". Bekerja merupakan salah satu sebab pokok yang memungkinkan manusia memiliki harta kekayaan. Untuk memungkinkan manusia berusaha mencari nafkah, Allah SWT. melapangkan bumi serta menyediakan berbagai fasilitas yang dapat dimanfaatkan manusia untuk mencari rezeki. Sesuai dengan firman Allah SWT. (Q.S. Al-Mulk [67]: 15).

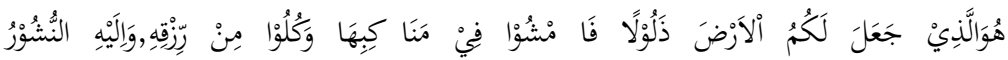

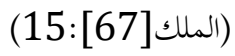

Artinya: "Dialah yang menjadikan bumi untuk kamu,maka berjelajalah di segala penjurunya dan makan

\footnotetext{
1 Iqbal Fauzi, "strategi pengembangan usaha mikro, kecil dan menengah (UMKM), (atudi kasus pada UD. Genteng pres super soka masinal desa pancasan kacamatan ajibarang kabupaten banyumas)".skripsi. (online), (https://jurnal.iainpalu.id).di akses pa 20 Desember 2020.
} 
sebagian dari rezeki-nya. Dan hanya kepada-nyalah kamu (kembali setelah) di bangkitkan".(Q.S Al-Mulk [67]: 15).

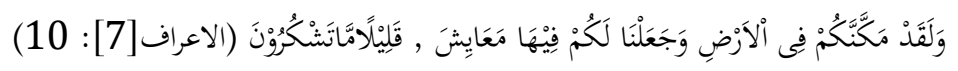

Artinya: "Dan sungguh, kami telah menempatkan kamu di bumi dan di sana kami sediakan (sumber) penghidupan untukmu". (Q.S. Al-A'raf [7]: 10). ${ }^{2}$

Di samping anjuran mencari rezeki, Islam sangat menekankan (mewajibkan) aspek kehalalannya, baik dari sisi perolehan maupun pendayagunaannya (pengelolaan dan perolehan. ${ }^{3}$

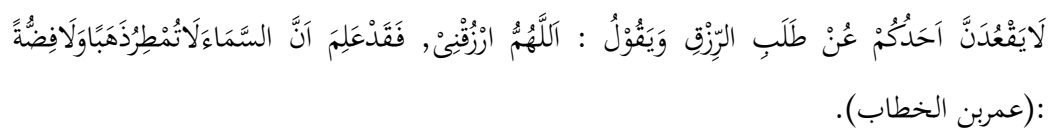

Artinya: "Janganlah sekali-kali di antara kalian ada yang duduk-duduk enggan mencari rezeki dan (hanya) berdo'a "Ya Allah limpahkanlah rezeki kepdaku", padahal ia telah mengetahui bahwa langit tidak menurunkan hujan emas dan perak" $^{\prime \prime}$

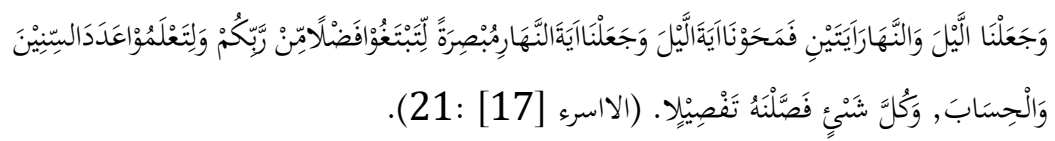

Artinya: "dan kami jadikan malam dan siang sebagai dua tanda, lalu kami hapuskan tanda malam dan kami jadikan tanda siang itu terang, agar kamu mencari karunia dari tuhanmu, dan supaya kamu menegtahui bilangan tahun-tahundan

\footnotetext{
${ }^{2}$ Usman el-Qurtuby, al-Qur'an Hafal Mudah, terjemahan abdul aziz abdul rauf \& andi subarka (bandung: cordoba, 2020), 563.

3 Nana Herdiana Abdurrahman, manajemen bisnis syariah dan kewirausahaan. Hal, 265.

${ }^{4}$ Hadist Umar Bin Khatab, Manajemen Bisnis Syariah Dan Kewirausahaan, hal 251.
} 
perhitungan. Dan segala sesuatu telah kami terangkan dengan jelas. (QS AL-ISRA' 17:12). ${ }^{5}$

Usaha adalah suatu kegiatan yang mengerahkan tenaga, badan dan pikiran untuk mencapai apa yang telah direncanakan sesuai dengan harapannya, Pada masa yang sudah modern ini mencari suatu pekerjaan merupakan suatu hal yang sangat sulit, Dibutuhkan segala kemampuan, pengalaman, dan identitas yang bisa mendukung dalam usaha untuk mendapatkan sebuah pekerjaan yang mumpuni atau berpenghasilan tinggi. ${ }^{6}$

Sebagai upaya perwujudan struktur perekonomian nasional yang semakin seimbang, berkembang dan berkeadilan maka langkah pemerintah adalah pemberdayaan usaha mikro, kecil dan menengah. Yang dimaksud dengan pemberdayaan adalah pengembangan iklim yang tenang, pemberian kesempatan berusaha, dukungan, perlindungan dan pengembangan usaha seluas-luasnya, sehingga bisa meningkatkan kedudukan peran potensi UMKM dalam mewujudkan pertumbuhan ekonomi, pemerataan dan peningkatan pendapatan rakyat, menciptakan lapangan kerja dan pemberantasan kemiskinan.

Peran atau keberadaan UMKM sangat bermanfaat dalam pendistribusian pendapatan masyarakat. UMKM sangat berpengaruh dalam membantu pertumbuhan ekonomi, selain berperan dalam pertumbuhan pekonomian, UMKM juga sangat berperan dalam mengatasi pengangguran7. Ada beberapa alasan utama suatu negara harus mendorong usaha kecil yang

\footnotetext{
5 Usman el-Qurtuby, al-Qur'an Hafal Mudah, terjemahan abdul aziz abdul rauf \& andi subarka (bandung: cordoba, 2020), 282.

${ }^{6} \mathrm{P}$. Eko Prasetyo, peran usaha mikro kecil dan menengah dalam penanggulangan kemiskinan pengangguran, 8, September2008, Jurnal Akmenika Upy, (Onlene),Vol,2,( http://scolar.goole.).

7 Feni Dwi Anggraini, Imam Harjanto, Ainul Hayat, "penembangan usaha mikro kecil dan menengah (UMKM) melalui fasilitasi pihak eksternal dan potensi internal", jurnal administrasi publik, 2 (januari, 2013),
} 
ada untuk terus maju atau berkembang diantaranya adalah: alasan yang pertama yaitu pada umumnya usaha kecil cenderung memiliki kinerja lebih baik dalam menghasilkan tenaga kerja yang produktif. Alasan yang kedua yaitu sering mencapai peningkatan produktivitasnya dengan melalui prubahan teknologi dan investasi. Alasan ke tiga yaitu ternyata usaha kecil memiliki keunggulan dalam segi fleksibilitas dibandingkan dengan perusahaan besar.

Usaha mikro berperan penting untuk membangun perekonomian indonesia khususnya masyarakat kelas bawah untuk memenuhi kebutuhan dalam sehari-hari terlebih dimasa yang akan mendatang. Di dalam hal ini usaha mikro berperan sangat besar terhadap kegiatan ekonomi masyarakat. Berikut menurut departemen koprasi, peran penting usaha mikro adalah:

1. Mencitakan pasar baru baru dan sumber ekonomi.

2. Sebagai pemeran utama di dalam kegiatan ekonomi.

3. Pemain penting di dalam pembangunan perekonomian lokal dan pemberdayaan masyarakat. ${ }^{8}$

Di dusun gunung timur desa gunung kesan, usaha genteng menjadi bagian dari usaha yang sangat diminati oleh masyarakat dibandingkan dengan pekerjaan lainnya, semisal menjadi petani ataupun bekerja merantau ke luar negeri karena pada umumnya usaha genteng bagi masyarakat sekitar dapat mencukupi semua kebutuhan hidup dan bahkan lebih dari itu misalnya mereka mampu menunaikan ibadah haji ketanah suci, membangun rumah gedung, membeli mobil dan lain sebagainya yang murni hasil dari usaha genteng. Usaha genteng membutuhkan tenaga kerja karena tidak bisa dikelola oleh individu sehingga mampu menciptakan lapangan kerja

\footnotetext{
8 Erwansyah, "peran usaha mikro kecil menengah (UMKM) sektor pangan terhadap kesejahteraan masyarakat dalam persepektif ekonomi islam", skripsi diakses pada tahun 2019,(online), (https//google scholar).
} 
serta tidak membutuhkan syarat sebagaimana profesi yang lainnya, semisal harus mempunyai ijazah sehingga minat masyarakat lebih besar. Usaha genteng ini mampu memperbaiki perekonomian di dusun gunung timur desa gunung kesan karena menjadi mata pencarian mayoritas masyarakat.

\section{KAJIAN PUSTAKA}

\section{Pengertian Usaha Mikro Kecil dan Menengah}

Usaha mikro adalah suatu kegiatan ekonomi masyarakat yang bersekala kecil dan bersifat tradisional dalam bentuk pembuatannya. Sedangkan usaha mikro kecil dan menengah (UMKM) secara istilah merujuk pada usaha kecil yang di kerjakan oleh masyarakat yang bukan merupakan koprasi. Sedangkan secara umum usaha UMKM yaitu usaha yang di kelola dan dimiliki oleh perseorangan yang produktif atau badan usaha yang merujuk pada usaha ekonomi yang produktif dengan keriteria yang sudah ditetapkan oleh undang-undang nomer 20 tahun 2018.

Ada beberapa pengertian UMKM menurut para ahli di antaranya yaitu:

a. Menurut pendapat Adi M. Kwartono UMKM adalah kegiatan ekonomi masyarakat yang mempunyai pendapatan bersih 200.000.000,00 (dua ratus juta rupiah) pertahunnya.

b. Menurut pendapat Rudjito (2013) UMKM adalah usaha yang berperan sangat penting di dalam perekonomian indonesia, baik secara jumlah usahanya maupun secara lapangan kerja yang di ciptakan.

c. Menurut pendapat Ina Primiana UMKM adalah pengembangan empat (industri manufaktur, Agribisnis, Bisnis kelautan, Sumber daya manusia). 
ekonomi utama yang menjadi penggerak perkembangan indonesia. ${ }^{9}$

Ada beberapa kriteria UMKM RI menurut UU No. 20 Tahun 2008. Untuk mengetahui jenis usaha apa yang sedang di lakukan atau di jalankan terlebih dahulu perlu memperhatikan kriteria-kriteriannya. Hal ini sangat penting karena akan mempengaruhi proses menentukan besarnya pajak yang akan dibayar oleh pemilik UMKM dan juga proses per ijinannya. Berikut definisi pengertian dan kriteria usaha mikro, kecil dan menengah.

a. Usaha Mikro adalah usaha yang mempunyai pendapatan bersih sebanyak Rp 50.000.000.00 (lima puluh juta rupiah), dan tidak termasuk pada tanah yang di tempati usaha dan juga bangunannya. Setiap tahunnya pendapatan paling besar 300.000.000.00 (tiga ratus juta rupiah).

b. Usaha Kecil adalah suatu usaha ekonomi produktif yang dimiliki kelompok atau perseorangan dan bukan badan usaha cabang dari suatu peruhasahaan utama. Usaha kecil ini mempunyai pendapatan bersih sebanyak Rp 50.000.000,00 (lima puluh juta rupiah), dengan maksimal yang di butuhkan sebanyak 500.000.000,00 (lima ratus juta rupiah) dari hasil bisnis bersih penjualan pertahunnya antara 300.000.000,00 (tiga ratus juta rupiah) dan yang paling banyak 2,5.000.000.000,00 (dua milyar lima ratus juta rupiah).

c. Usaha Menengah adalah uhasa ekonomi produktif dan bukan merupakan anak perusahaan dari perusahaan pusat. Dengan mempunyai total pendapatan bersih yang sudah diatur oleh peraturan undang-undangnya.

9 Parta Ibeng, Usaha Mikro Kecil Menegah. Jurnal, Online, (ttps://www.maxmanroe.com). diaskses pada 8 mei 2018. 
Usaha menengah sering juga dikategorikan bisnis besar karena pendapatan bersih yang dimiliki oleh usaha ini emncapai lebih dari Rp 500.000.000,00 (lima ratus juta rupiah) hingga $\mathrm{Rp} 10.000 .000 .000,00$ ( sepuluh milyar rupiah tanah tempat usaha dan bangunan tidak termasuk. Hasil penjualan tahunan lebih dari Rp 2,500.000.000,00 (dua milyar lima ratus juta rupiah), sampai dengan paling banyak $\mathrm{Rp}$ 50.000.000.000,00 (lima puluh milyar rupiah). ${ }^{10}$

\section{Kerajinan Genteng}

Kerajinan adalah suatu hasil industri atau suatu barang yang dibuat dari karya atau usaha masyarakat secara mandiri dalam menggunakan keterampilan dan sebagai upaya untuk memperbaiki perekonomian mereka. ${ }^{11}$ Sedangkan genteng adalah merupakan salah satu jenis penutup atap rumah yang paling umum digunakan di Indonesia. Genteng seperti penutup atap lainnya yang berfungsi sebagai pelindung dari panas dan hujan. Selain itu tampilan genteng menjadi hal yang penting dalam membantu penampilan akses sebuah rumah.

Dengan mengetahui jenis genteng beserta kelebihan dan kekurangannya, diharapkan konsummen dapat memilih genteng yang tepat untuk rumahnya. Pemilihan jenis dan warna genteng yang tepat tentunya akan menambah keindahan rumah tersebut. Sebagai konsumen haruslah pintar-pintar dalam memilih jenis genteng. karena sebagai pelindung rumah ini harus tahan dari sengatan panas mata hari atau terpaan hujan, atap rumah seharusnya berdaya tahan tinggi, tak mengidap banyak kelemahan. Apabila Anda

\footnotetext{
${ }^{10}$ Yuli Rahmini Suci, Perkembangan UKMK (Usaha Mikro Kecil Dan Menengah) Jurnal,(online)(https://www.neliti.com/publication). Diakses pada tahun 2017.

${ }^{11}$ Ayie Eva Yuliana, Pengembangan Industri Kecil Kerajinan Genteng Di Kabupaten Kebumen. Jurnal (https://doi.org/10.1529/edaj.v2i3.1975). Di akses pada 15 mei 2019.
} 
memiliki rumah, tentu genteng menjadi satu hal yang sangat dibutuhkan. Sebagai atap yang dapat menjadi pelindung tempat tinggal kita. Maka dengan fungsinya yang penting ini keberadaanya sangat dibutuhkan sekali. Siapa saja yang membangun rumah mesti perlu untuk membeli genteng. Para arsitektur sangat memandang sesuatu yang pokok dalam pemilihan genteng bagi bangunan rumah yang akan dibangun. ${ }^{12}$

\section{Pengertian Penanggulangan}

Adapun kata Penanggulangan berasal dari kata dasar tanggulang, mempunyai arti dalam kelas nominal atau kata benda sehingga penanggulangan dapat menyatakan nama dari seseorang, tempat, serta semua benda dan segala yang dapat dibedakan. ${ }^{13}$

Banyaknya angka pengangguran menjadi suatu masalah yang harus diselesaikan secepatnya karena akan berpengaruh terhadap pertumbuhan ekonomi indonesia. Berharap pemerintah bisa mengatasi dengan menumbuhkan jiwa kewirausahaan UKM ataupun UMKM dengan memberikan pengetahuan atau bimbingan dengan cara memberikan pelatihan atau praktek terhadap para pengangguran. Pengangguran berpengaruh buruk terhadap ekonomi, mental dan sosial.

Pengangguran adalah orang yang ingin bekerja tetapi tidak memiliki pekerjaan. Ada beberapa macam pengangguran di antaranya:

a. Setengah pengangguran adalah tenaga kerja yang kurang dari 35 jam perminggu.

b. Pengangguran secara tebuka adalah orang yang benar-benar tidak mempunyai pekerjaan.

\footnotetext{
${ }^{12}$ Jamrud Aminuddin, Aris Haryandi, Sunardi Sunardi, proses Pembuatan genteng sokka kebumen. Jurnal,(Online)(https://goole.ac.id). Diakses pada 20 juli 2019.

13KBBI (Online) diakses 4 januari 2020
} 
c. Pengangguran terselubung adalah tenaga kerja yang tidak bisa bekerja secara meksimal di kerenakan suatu alasan yang tertentu

\section{Penyebab pengangguran}

Menurut pendapat Sudrajad. Banyak pemuda-pemudi yang sudah masuk usia kerja, tetapi belum mendapatkan pekerjaan. Hal itu sebenarnya bukan berarti di masyarakat tidak tersedia lapangan pekerjaan. Ternyata dibidang swasta cukup tersedia lapangan pekerjaan, seperti perbengkelan, industri kecil, sales, asuransi,dan lain sebagainya. Pada umumnya para pengangguran kurang tertarik akan pekerjaan swasta dengan alasan gengsi atau martabat mereka menjadi rendah dimata masyarakat, pendapat tersebut sama sekali tidak benar. Hal tersebut hanya merupakan perasaan mereka pada umumnya menginginkan bekerja sebagai pegawai negeri atau sebagai amtenar.

Bekerja sebagai pengawai negeri menurut mereka mempunyai prestasi yang tinggi dimasyarakat. Hal itu merupakan jabatan yang turun-temurun dari kakek ninik mereka. Keinginan menjadi pengawai negeri, amtenar atau priyayi, dan menganggap pekerjaan lainnya lebih rendah dan menurunkan martabat orang bersangkutan adalah tidak benar. Pandangan tersebut masih hidup pada sebagian masyarakat kita akibat warisan penjajahan belandan selama 530 tahun. Pandangan tersebut harus barengsur-ansur dihilangkan. Pada zaman kemerdekaan ini sangat diperlukan pengembangan di segala bidang terutama pada sektor pertanian, perdagangan, dan jasa. Pembangunan tersebut memerlukan penanganan khusus dari para wiraswastawan yang tangguh dan andal.

Menurut pendapat Sudrajad penyebab pengangguran yang seharusnya dijadikan prioritas untuk ditangani oleh para wirasuwasta diantaranya yaitu:

a. Pertumbuhan Ekonomi. Krisis ekonomi global yang berkepanjangan memberikan pengaruh 
pertumbuhan ekonomi yang kurang menguntungkan apalagi disertai dengan perkembangan produk yang cukup tinggi. Hal itu mengakibatkan pertumbuhan ekonomi semakin berat yang berarti tingkat investasi yang dilakukan pemerintah maupun swasta lamban.

b. Menemui Jalan Buntu Dalam Mencari Pekerjaan. Karena sulit mencari pekerjaan setelah melamar kemana-mana dan hasilnya selalu nihil, akhirnya pencari kerja menjadi apatis. Mereka kehilangan kepercayaan diri bahwa sesungguhnya masih banyak lapangan kerja disekitar tempat tinggal mereka. Mereka lupa bahwa sebenarnya bekerja tidak hanya di perusahaan ataupun menjadi pengawai negeri. Banyak bidang lain disekitar mereka seperti peternakan, perdangangan, jasa, industri kecil, dan lain sebgianya yang belum ditangani ${ }^{14}$.

\section{Pengertian Pengangguran}

Pengangguran menurut Iskandar Putong (2003) merupakan penduduk yang tidak bekerja tetapi sedang mencari pekerjaan atau sedang mempersiapkan suatu usaha baru, atau penduduk yang tidak mencari pekerjaan karena tidak mungkin mendapatkan pekerjaan (discouraged workers) atau penduduk yang tidak mencari pekerjaan karena sudah diterima bekerja atau mempunyai pekerjaan tapi belum bekerja (future starts).

Berikut adalah lima penyebab terus meningkatnya angka pengangguran yang ada diindonesia.

${ }^{14}$ Sudrajad, S.E., Kiat Mengantaskan Pengangguran Melalui Wirausaha.dicetakan pertama, maret 1999, cetakan kedua, november 2000. N. 18 Jakarta 13220. Hal 8. 
a. Rendahnya jiwa kewirausahaan yang dimiliki angkatan kerja.

b. Besarnya jumlah angkatan kerja yang tidak memiliki kualifikasi keterampilan yang dibutuhkan pasar kerja

c. Terbatasnya lowongan pekerjaan sector formal

d. Rendahnya kualitas dan kuantitas kompetensi yang dimilki angkatan kerja.

e. Globalisasi. ${ }^{15}$

Hal tersebut dapat dibuktikan dengan tumbuhnya wiraswasta baru seperti jamur di musim hujan. Di dalam era pembangunan dalam mewujudkan cita-cita bangsa, munculnya pengusaha muda yang berkualitas merupakan pionir untuk menunjang suksesnya pembangunan. Usaha wiraswasta tidak hanya yang berskala besar, yang berskala kecil pun sangat diperlukan kehadirannya. Mereka dapat saling menunjang dengan wiraswasta yang berskala menengah maupun yang berskala besar. Bidang usaha wiraswasta banyak menyediakan lapangan kerja. Di dalam turut menumbuh kembangkan usaha wiraswasta terutama yang berskala kecil, buku ini menyumbangkan stimulasi gairah kepada memuda-pemudi yang sedang mencari pekerjaan untuk menjadi wiraswastawan yang mendiri. ${ }^{16}$ Sedangkan pengertian ketenaga kerjaan adalah setiap orang yang bisa malakukan pekerjaan yang bermanfaat atau berfaedah menghasilkan produk atau barang dan jasa baik memenuhi kebutuhan orang masyarakat ataupun kebutuhan diri sendiri.

\section{Aspek tenaga kerja}

Kegiatan usaha pengrajin genteng pada umumnya bersifat industri rumah tangga yang mana para pekerjanya

${ }_{15}$ Arif Isnaini 2012, Berani Berwirausaha, (Surabaya : INSAN CENDEKIA).14

16Sudrajad, kiat mengentaskan pengangguran melalui wirausaha. Hal.10 
atau yang manjadi tenaga kerja sebagian besar dari anggota keluarga. Dalam membuat kerajinan genteng biasanya di dapatkan dari pengetahuan dan pengalaman dari orang tuanya yang sudah turun temurun. Sehingga tidak lagi membutuhkan pendidikan yang khusus, karena cara memproduksinyapun sangat mudah (tidak begitu sulit).

Sedangkan jumlah tenaga kerja yang dibutuhkan oleh pengusaha genteng sekitar 2-6 orang. Sebagian besar Tenaga kerja yang digunakan berasal dari keluarga sendiri dan sebagian berasal dari orang lain atau luar keluarga. Bagi tenaga kerja yang berasal dari luar keluarga, akan di beri gaji atau upah, baik berupa mingguan, harian, bulanan, bahkan ada yang sampek tahunan tergantung pada kebutuhan ekonomi hidupnya. Sehingga para pengusaha genteng tidak membutuhkan tenaga kerja sebagai administrasi dan sebagian besar tenaga kerjanya yaitu tenaga produksi. Dilihat dari tingkat pendidikan tenaga kerja, maka tenaga kerja yang memproduksi genteng sebagian besar hanya dari lulusan SD (sekolah dasar) dan bahkan banyak sekali yang tidak lulus sekolah. Karena bekerja di dalam bidang ini, tidak di perlukan pengetahuan dari bangku sekolah, namun dibutuhkan kemampuan fisiknya. Jika fisiknya kuat atau mampu bekerja bisa menghasilkan genteng. ${ }^{17}$

\section{Pengembangan Industri}

Pengambangan dapat dilakukan sebagai usaha untuk memajukan atau meningkatkan sesuatu yang sudah ada sehingga memiliki nilai yang lebih tinggi. Sedangkan industri adalah suatu usaha menusia untuk mengelola bahan mentah menjadi suatu barang setengah jadi atau barang jadi sehingga

\footnotetext{
${ }^{17}$ Didik Sulistyono, analisis fungsi produksi industri kerajinan genteng di Kacamatan Cawas Kabupaten Klaten, skripsi, (online), (https://didiksulistiyono.ic).
} 
dapat mendatangkan manfaat yang lebih besar untuk manusia. 18

\section{METODE PENELITIAN}

Penelitian ini menggunakan metode studi kasus dengan pendekatan kualitatif. Sedangkan jenis penelitian yang dilakukan berupa penelitian deskriptif karena bertujuan untuk menghasilkan berupa kata-kata tertulis atau lisan dari orang dan perilaku yang dapat diamati. Dalam penelitian ini, peneliti mengambil lokasi di dusun gunung timur desa gunung kesan kaca matan karang penang kabupaten sampang.

Untuk bisa mendapatka data yang maksimal, maka pengumpulan data dilakukan secara strategis. Kemudian, peneliti melakukan tiga langkah dalam tehnik atau prosedur pengumpulan data dengan cara observasi, wawancara secara terstruktur, dan dokumentasi. Setelah peneliti mendapatkan data dari prosedur masing-masing pengumpulan data, peneliti akan merangkum dan menganalisis semua data yang sudah diperoleh sehingga menjadi data yang mudah dipahami atau dicermati. Analisis data yang di gunakan peneliti ada tiga yaitu produksi data, penyajian data, kesimpulan data

\section{HASIL DAN ANALISIS}

\section{Peran usaha genteng dalam mananggulangi pengangguran di dusun gunung timur desa gunung kesan.}

Pada dasarnya peran usaha genteng sangatlah dibutuhkan oleh masyarakat itu sendiri dengan bertujuan usaha mareka bisa memberikan dampak yang baik bagi

\footnotetext{
18 Levi Martin Hadiyanti, Analisis Pengembangan Industri Kecil Kerajinan Genteng Dalam Upaya Meningkatkan Kesejahteraan Pengrajin Persepektif Ekonomi Islam, Skripsi (Online), (http://media.neliti.com), di akses pada 15 mei 2019.
} 
masyarakat kecil. ${ }^{19}$ Harga genteng selalu mangalami naik turun (pasang surut), bahkan bahan baku yang digunakan juga mengalami kenaikan. Usaha genteng di dusun gunung timur desa gunung kesan cukup banyak memberikan kontribusi penyerapan tenaga kerja sehingga dapat mengurangi jumlah pengangguran dan menambah pendapatan masyarakat. Usaha genteng masuk pada katagori usaha kecil dan usaha rumahan sehingga bisa menampung cukup banyak karyawan atau pekerja. Hal ini sudah menjadi bukti dengan adanya peran usaha genteng bisa membantu mangurangi jumlah pengangguran dan mengatasi permasalahan ekonomi yang ada seperti halnya:

1. Menyerap Tenaga Kerja, Mengurangi Jumlah Pengangguran

Semakin banyaknya atau bertambahnya jumlah penduduk maka akan berpengaruh terhadap permasalahan dalam mencari suatu pekerjaan apalagi pada zaman sekarang ini sudah semakin berkembang. Berbagai macam industri-industri baru yang dibuka dengan tujuan dapat memberikan peluang pekerjaan dan bisa berdampak baik bagi orang-orang terutama bagi masyarakat yang tidak mempunyai pekerjaan. Berdasarkan dari hasil penelitian terdahulu dan juga hasil dari pengamatan peneliti bahwa peran usaha genteng dapat membuka lapangan pekerjaan bagi semua masyarakat tanpa terkeculi baik laki-laki ataupun perempuan sehingga dapat mengurangi jumlah pengangguran dan meningkatkan ekonomi keluarga ${ }^{20}$.

19 Ana Normaya, "Peranan Industri Genteng Dalam Menaningkatkan Kesejahteraan Ekonomi Masyarakat Muslim Didusun Temlek Desa Gadungan Kacamatan Kabupaten Kediri" , http://www etheses.iainkediri.ac.id, 15 (Maret, 2019).

20 Ana Normaya, "Peranan Industri Genteng Dalam Menaningkatkan Kesejahteraan Ekonomi Masyarakat Muslim Didusun Temlek Desa Gadungan 
Seperti halnya yang dilakukan para pemproduksi genteng pada zaman dahulu, masyarakat di dusun gunung timur desa gunung kesan memproduksi genteng secara mandiri kerena menurut pemikiran mereka lebih cepat kembalinya modal yang telah dipakai dan setelah itu bisa dibuat modal lagi. Namun setelah perubahan tahun ketahun para pemilik usaha genteng lebih memilih menggunakan atau memakai tenaga kerja dari orangorang yang mau bekerjauntuk membuat genteng dan semacamnya. Hal ini juga bertujuan untuk membuka lapangan pekerjaan bagi orang-orang yang membutuhkan pekerjaan dan memperbaiki perekonomian dalam kelurganya. Keberadaan usaha genteng ini sangat berperan dan cukup banyak mengunakan atau menyerap para tenaga kerja karena lebih banyak dibutuhkan didalam memproduksi genteng, selain proses pencetakan genteng tidak bisa dilakukan sendirinya atau dilakukan 1 orang atau perorangan.

\section{Masalah Dalam Pengangguran}

Selama ini masyarakat berfikir bahwa dengan sekolah yang tinggi seperti halnyan kuliah, menjadi salah satu sarana untuk mendapatkan suatu pekerjaan yang lebih nyaman dan pendapatan atau gaji lebi tinggi, sebenarnya pemikiran tersebut tidak salah dan juga tidak semuanya benar. Didalam suatu proses belajar mengajar di sekolah membantu seseorang untuk bisa berpikir dengan baik, bijaksana, dan juga bisa menghadapi semua hal yang ada, dan semua itu dibutuhkan didalam suatu pekerjaan. Namun bukan berarti bersekolah sampai keperguruan tinggi menjamin seseorang mendapatkan pekerjaan yang layak dan mapan serta kehidupan yang

Kacamatan Kabupaten Kediri" , http://www etheses.iainkediri.ac.id, 15 (Maret, 2019). 
sempurna akan tetapi semua itu tidak bisa didapatkan dengan sangat mudah.

Dalam setiap tahun lulusan dari perguruan tinggi atau Serjana hampir mangalami inflasi. Hal ini dibuktikan bahwa tidak semua orang yang sudah lulus dari perguruan tinggi atau serjana akan sukses. Walaupun faktanya ada sebagian yang sukses setelah lulus dari bangku sekolah atau kuliah dan juga mendapatkan pekerjaan yang mapan secara financial, akan tetapi hal itu bukan karena mereka telah lulus sekolah atau kuliah saja, melainkan karena di dorong oleh kemaunya dan juga ketekunannya. Jadi, lulus sekolah atau kuliah jangan dijadikan sebagai tolak ukur bagi yang lain karena semua itu tergantung pada kemauan dan ketekunan dalam setiap usaha yang dilakukan. Sehingga orang tersebut mampu dalam menyikapi setiap permasalah dalam kehidupannya dan pekerjaannya.

Sekolah tidak perlu dijadikan sasaran terhadap masalah kurangnya pertumbuhan usaha ataupun masalah pengangguran. Masalah ini perlu di luruskan karena cukup banyak orang yang menyalahkan bangku sekolah menjadi salah satu penyebabnya. Bahkan ada juga yang mengatakan bahwa bangku sekolah kita gagal dalam pertumbuhan usaha karena pada saat ini masih saja banyak lulusan serjana yang menjadi pengangguran. Padahal tujuan utama dari bangku sekolah yaitu memberikan ilmu sebanyak-banyaknya kepada murid-muridnya atau kepada anak didiknya, sehingga menjadi tepat kerena pendidikan dapat dikatakan berhasil dalam kesuksesan secara intelektual. Jadi bukan bangku sokolah yang menyebabkan adanya pengangguran pada lulusan perguruan tinggi atau lulusan serjana tetapi dikarenakan dari mereka sendiri yang tidak ada kemauan mempraktekan ilmu pengetahuan yang sudah ia dapatkan selama didalam bangku 
sekolah. Hal ini yang menjadi penyebab seseorang tidak sukses secara finansial atau menjadi pengangguran ${ }^{21}$.

Pada dasarnya pengangguran disebabkan oleh jumlah para pencari pekerjaan atau jumlah angkatan kerja yang tidak sebanding dengan jumlah lapangan pekerjaan yang sudah ada. Pengangguran seringkali menjadi penyebab masalah dalam perkembangan ekonomi karena dengan adanya pengangguran, produktivitas, dan penghasilan masyarakat akan berkurang sehingga bisa menimbulkan atau menyebabkan masalah kemiskinan dan juga masalah-masalah yang lainnya. Orang yang terlalu lama menjadi pengangguran akan berpengaruh pada masalah psikoligisnya dan juga dalam masalah keluarganya. Selain itu jumlah pengangguran yang tinggi juga berdampak buruk dan menimbulkan kekacauan kedalam keamanan, politik, sosial, dan pertumbuhan ekonomi22.

\section{Mananggulangi Pengangguran}

Pengangguran merupakan istilah dari seorang yang tidak memiliki pekerjaan atau orang yang sama sekali tidak bekerja. Pengangguran terjadi karena jumlah orang yang mencari pekerjaan lebih banyak dari pada lapangan pekerjaan itu sendiri. Hal ini sangat berpengaruh terhadap perekonomian masyarakat karena dapat manurunkan pendapatan dan produktivitas.

Pengangguran merupakan keadaan yang sangat memperhatinkan dan dapat mempengaruhi terhadap perkembangan perekonomian negara, maka dari itu setiap negara terutama indonesia harus melakukan pencegahan. Paling tidak mengurangi jumlah pengangguran yang ada. Hal ini bisa dilakukan bekerjasama dengan lembaga terkait,

\footnotetext{
${ }^{21}$ Arif Isnaini, “Berani Berwirausaha”, pendidikan, pengangguran, pencari kerja, dan wwirausaha (Surabaya: Isan cendekia, 2012), 9.

${ }^{22}$ Arif Isnaini, “Berani Berwirausaha”.... hal, 13.
} 
pengusaha, instansi dan masyarakat, industri dan juga pemerintah.

Solusi ini dilakukan supaya bisa mengurangi jumlah pengangguran karena setiap tahun pasti akan bertambah meningkat jumlah para pencari kerja, kebutuhan perusahaan, kebijakan pemerintah dan hal yang lainnya dan yang pasti bisa mempengaruhi meningkatnya jumlah pengangguran dengan adanya sumber daya dari mesin yang semakin modern setiap tahun. Setiap waktu sangat dibutuhkan pembaruan supaya selalu mendapatkan solusi yang baru apalagi di era modern ini yang semuanya serba uang.

Dengan adanya lapangan pekerjaan maka akan dapat mengurangi jumlah pengangguran. ${ }^{23}$ untuk mengurangin jumlah pengangguran yang ada didesa gunung kesan maka masyarakat gunung kesan membuka lapangan pekerjaan dengan membuka usaha genteng, dalam usaha genteng tidak bisa dilakukan sendirian atau perorangan saja sehingga dibutuhkan banyak tenaga kerja dan hal itu bisa mengurangi terhadap jumlah pengangguran yang ada, dan untuk melamar kerja dalam usaha genteng sangatlah mudah tidak diperlukan ijazah, dan juga kemampuan yang khusus, karena siapapun bisa bekerja asalkan mempunyai kemauan untuk bekerja.

Jumlah tenaga kerja yang dibutuhkan dalam usaha genteng Di Dusun Gunung Timur Desa Gunung Kesan berbedabeda. Ada yang membutuhkan 2-5 ada juga yang membutuhkan 9-12 tenaga pekerja. Hal ini tergantung dari situasi dan kondisinya. Dalam setiap proses pembuatan atau produksi genteng. Teknik pembuatan genteng sangatlah sederhana sehingga para pekerja pemula mudah untuk mempelajarinya. Usaha genteng selain mengurangi jumlah pengangguran juga bisa memperbaiki dan meningkatkan perekonomian masyarakat. Hal ini sudah terbukti, mengingat

23 Ervina, "Cara Menurunkan Angka Pengangguran Yang Tepat", skripsi. http://www.talenta.ac. (21 maret 2020). 
pada saat ini meskipun adanya wabah virus 19 (corona), usaha genteng tetap bisa bertahan didalam krisis ekonomi ini, meskipun tidak begitu normal, seperti ada macetnya karena masih new normal tetapi tetap saja masih bisa bertahan dan aktif diproduksi.

Pada dasarnya usaha genteng bukan hanya memperbaiki perekonomian masyarakat dusun gunung timur desan gunung kesan tetapi juga berdampak pada daerah, karena penjualan genteng tidak hanya berputar didesa gunung kesan saja akan tetapi penjualan genteng sampai keberbagai daerah. oleh karena itu usaha genteng dapat membuka lowongan kerja dan bisa mengurangi jumlah kemiskinan atupun jumlah pengangguran yang ada. Dan pendapatan dari usaha genteng juga cukup tinggi dan cukup untuk memenuhi kebutuhan hidup dalam keluarga bahkan lebih, oleh karena itu masyarakat gunung kesan manyoritas memproduksi genteng dan hasil peroduksiya bukan hanya di jual di pedesaan ataupun pulau madura saja. Namun juga banyak penjualan ke jawa, di luar jawa timur dan sebagainya.

\section{Maningkatkan Pendapatan Masyarakat}

Penghasilan atau pendapatan yang di dapatkan masyarakat perlu di perhatikan untuk memenuhi kebutuhan didalam kehidupan sehari-hari. Tanpa adanya pendapatan bagi setiap masyarakat yang sudah memasuki katagori mampu untuk bekerja, maka nantinya akan berdampak kepada permasalahan ekonomi ${ }^{24}$.

Seperti halnya usaha produksi genteng di dusun gunung timur desa gunung kesan mampu memberikan peran yang sangat penting bagi masyarakat sekitar yaitu dapat meningkatkan penghasilan atau pendapatan masyarakat

24 Ana normaya, "Peranan Industri Genteng Dalam Menaningkatkan Kesejahteraan Ekonomi Masyarakat Muslim Didusun Temlek Desa Gadungan Kacamatan Kabupaten Kediri", http://www etheses.iainkediri.ac.id, 15 (Maret, 2019). 
sekitar. Hal ini sudah terbukti dengan adanya usaha produksi genteng pendapatan masyarakat mengalami peningkatan dengan sangat baik dan pastinya pendapatan yang diproleh ketika memproduksi genteng bagi para pengrajin genteng baik pemiliknya ataupun para pekerjanya sudah bisa dikatakan cukup untuk memenuhi kebutuhan hidup. Dibandingkan bekerja sebagai buruh tani yang pendapatannya tidak maksimal.

Hasil penelitian di atas sejalan dengan penelitian yang sudah ditemukan oleh siti susana dalam bahwa peranan home industri di desa mengkirau kacamatan merbaru dapat menstabilkan atau meningkatkan pendapatan masyarakat. Dengan meningkatnya pendapatan maka akan meningkatkan kebutuhan masyarakat dan apabila kebutuhannya meningkat dengan baik maka secara otomatis masyarakat bisa hidup sejahtera baik dari segi sandang, panga dan juga mapan. ${ }^{25}$

Pendapatan bersih untuk pekerja genteng yang diproleh sebesar 840.000.00 - 1.200.000.00 dalam perbulannya dan hal itu tergantung pada kualitas dan macam genteng yang mereka buat. Melihat kenyataan ini berarti usaha genteng Di Desa Gunung Kesan tidak hanya dapat menanggulagi pengangguran tetapi juga dapat mengurangi angka kemiskinan.

Menurut ketentuan peraturan pemerintah kementrian sosial republik indonesia. nomor : 146 / HUK / 2013. Seseorang dapat dikatagorikan miskin apabila memiliki pendapatan perbulan dibawah $600.000 .{ }^{26}$ sedangkan pekerja genteng di gunung kesan perbulannya memiliki pendapatan sebesar 840.000-1.200.000.

\footnotetext{
25 Ana normaya, "peran industri genteng...., (http://www etheses.iainkediri.ac.id).

${ }^{26}$ Kementrian sosial republik indonesia tahun 2013.
} 


\section{KESIMPULAN}

Berdasarkan hasil penelitian dalam usaha genteng ini membutuhkan modal yang cukup besar dalam setiap bulanya. Seperti pembelian bahan bakar solar sekitar 45 liter bahkan lebih, tergantung pada pemakaian yang dibutuhkan dalam perbutannya. 270.000.00. Pembelian kayu bakar dalam 2 truk seharga 4.600.000.00-5.000.000.00, pembelian tanah liat dalam 1 damtruk seharga 200.000.00-300.000.00 dan yang paling banyak memakan biaya dalam usaha genteng ini tanah liat, karena tidak hanya membeli 1 damturk, namun harus membeli 1-12 damtruk dalam setiap bulannya.

Sedangkan mengenai gaji para pekerja usaha genteng bermacam-macam, tergantung dari kuantitas dan kualitasnya dan setiap pekerja memiliki gaji yang berbeda. Mulai dari 800.000.00 perbulan ataupun lebih banyak sesuai dengan hasil atau jumlah yang diproduksi. Adapun hasil bersih dari para pemilik usaha genteng berkisar sebesar 5.000.000.00 perbulan ataupun bisa lebih banyak, sesuai dengan tingkat kerajinan para pekerja dan kebutuhan pembeli. Pendapatan bersih untuk pekerja genteng yang diproleh sebesar 840.000.00 1.200.000.00 dalam perbulannya hal itu tergantung pada kualitas dan macam genteng yang diproduksi.

Menurut ketentuan peraturan pemerintah kementrian sosial republik indonesia. nomor : 146 / HUK / 2013. Seseorang dapat dikatagorikan miskin apabila memiliki pendapatan perbulan dibawah 600.000. sedangkan pekerja genteng di Gunung Kesan dalam perbulannya memiliki pendapatan sebesar 840.000-1.200.000. maka dari itu usaha genteng ini pempunyai peran penting didalam menanggulangi pengangguran dan selain itu juga dapat mengurangi angka kemiskinan. Berdasarkan dari hasil penelitian diatas maka dapat ditarik kesimpulan bahwa usaha genteng yang ada Di Dusun Gunung Timur Desa Gunung Kesan memiliki peran penting dalam upaya menanggulangi pengangguran, karena 
dengan adanya usaha genteng maka pendapatan yang di proleh semakin meningkat dan jumlah pengangguran yang ada di Desa Gunung Kesan semakin berkurang, karena dibutuhkannya tenaga pekerja dan terciptanya lapangan pekerjaan.

\section{DAFTAR PUSTAKA}

Abdul Aziz Abdul Rauf \& Andi Subarka. 2020. al-Qur'an Hafal Mudah, terjemahan. bandung: cordoba.

Abdurrahman Nana Herdiana. 2013. manajemen bisnis syariah dan kewirausahaan. Bandung: Pustaka Setia

Aminuddin, J., Haryadi, A., \& Sunardi, S. (2019). Proses

Pembuatan Genteng Sokka Kebumen. Dinamika Journal: Pengabdian Masyarakat, 1(4).

Arifin, N. R., Muhtadi, R., \& Herianingrum, S. (2019). Small and Medium Enterprise Perception of Halal Certification Post Formalization of Islamic City Branding. IJIBE (International Journal of Islamic Business Ethics), 4(1), 601-610.

Destiana, R. (2020). Faktor-Faktor Yang Mempengaruhi

Pembiayaan Usaha Mikro Kecil Dan Menengah Pada Bank Umum Syariah Dan Unit Usaha Syariah Di Provinsi Jawa Barat. FreakonomicS: Journal of Islamic Economics and Finance, 1(1), 1-11.

ERWANSYAH, E. (2019). Peranan Usaha Mikro Kecil Menengah (Umkm) Sektor Pangan Terhadap Kesejahteraan Masyarakat Dalam Perspektif Ekonomi Islam (Studi Pada UMKM di Kecamatan Balik Bukit, Lampung Barat) (Doctoral dissertation, UIN Raden Intan Lampung). Franita, R. (2016). Analisa pengangguran di Indonesia. Jurnal Ilmu Pengetahuan Sosial, 1(3), 88-93.

Hakim, L., \& Subairi, S. (2020). Membangun Bisnis Sebagai Profesi Etis. FreakonomicS: Journal of Islamic Economics and Finance, 1(1), 87-96. 
Iqbal Fauzi, 2018. Skripsi "Strategi Pengembangan Usaha Mikro, Kecil Dan Mennegah (UMKM) Study Kasus Pada UD. Genteng Pres Super Soka Masinal Desa Pancasan Kecamatan Ajibarang Kabupaten Banyumas ",

Isnaini Arif. 2012. Berani Berwirausaha. Surabaya: Insan cendekia.

Handiyanti Levi Martin.2017. Analisis Pengembangan Industri Kecil Kerajinan Genteng Dalam Upaya Meningkatkan Kesejahteraan Pengrajin Persepektif Ekonomi Islam.

Moleong J Lexy. 2005. Metodelogi Penelitian Kualitatif. Bandung: Remaja Rosda Karya.

Muhtadi, R. (2012). Sinergisme Baitul Maal wa tamwil (BMT) dengan badan usaha milik desa (BUMDES) sebagai alternatif penguatan UMKM Masyarakat Pedesaan di Madura. Jurnal Sains Ekonomi Islam Pascasarjana Universitas Airlangga.

Nurmaya, A. (2015). Peranan Industri Genteng dalam Meningkatkan Kesejahteraan Masyarakat Muslim di Dusun Templek Desa Gadungan Kecamatan Puncu Kabupaten Kediri (Doctoral dissertation, IAIN Kediri).

Poerwadarminta W.J.S. Kamus bahasa Indonesia, (online) (https://id.m.wikipedia.org/2018).

Prasetyo, P. E. (2008). Peran usaha mikro kecil dan menengah (umkm) dalam kebijakan penanggulangan kemiskinan dan pengangguran. Akmenika Upy, 2(1), p1-13.

Sari, T. I. (2018). Keberlanjutan Dan Kontribusi Industri Kecil Kerajinan Genteng Dalam Meningkatkan Kesejahteraan Pengrajin (Studi Kasus Pengrajin Genteng Desa Pancasan, Ajibarang, Banyumas) (Doctoral dissertation, IAIN Purwokerto).

Suci, Y. R. (2017). Perkembangan UMKM (Usaha mikro kecil dan menengah) di Indonesia. Cano Ekonomos, 6(1), 51-58. Sudewo, Arif. (2017). Kontribusi Pendapatan Pengrajin Industri Genteng Terhadap Total Pendapatan Rumah 
Tangga Dan Upaya Mengatasi Kendala Pada Industri Genteng Di Desa Sidoluhur Kecamatan Godean Kabupaten Sleman. Geo Educasia-S1, 2(5), 557-577.

Sudrajad. (2000). Kiat Mengantaskan Pengangguran Melalui Wirausaha. jakarta :bumi aksara.

Sugiyono, (2016), Metode Penelitian Kuantitatif dan Kualitatif dan $R \& D$. Bandung: CV ALFABETA

Sulistyono, D. (2003). Analisis fungsi produksi industri kerajinan genteng di Kecamatan Cawas Kabupaten Klaten. Yuliana, A. E. (2013). Strategi Pengembangan Industri Kecil Kerajinan Genteng di Kabupaten Kebumen. Economics Development Analysis Journal, 2(3). 